Maurer School of Law: Indiana University

Digital Repository@Maurer Law

Indiana Law Journal

Volume 6 | Issue 4

Article 1

$1-1931$

\title{
The Code Cause of Action: Joinder and Counterclaims
}

Bernard C. Gavit

Indiana University School of Law

Follow this and additional works at: https://www.repository.law.indiana.edu/ilj

Part of the Law Commons

\section{Recommended Citation}

Gavit, Bernard C. (1931) "The Code Cause of Action: Joinder and Counterclaims," Indiana Law Journal:

Vol. 6 : Iss. 4 , Article 1.

Available at: https://www.repository.law.indiana.edu/ilj/vol6/iss4/1

This Article is brought to you for free and open access by the Law School Journals at Digital Repository @ Maurer Law. It has been accepted for inclusion in Indiana Law Journal by an authorized editor of Digital Repository @ Maurer Law. For more information, please contact rvaughan@indiana.edu.

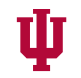

JEROME HALL LAW LIBRARY

INDIANA UNIVERSITY

Maurer School of Law
Bloomington 


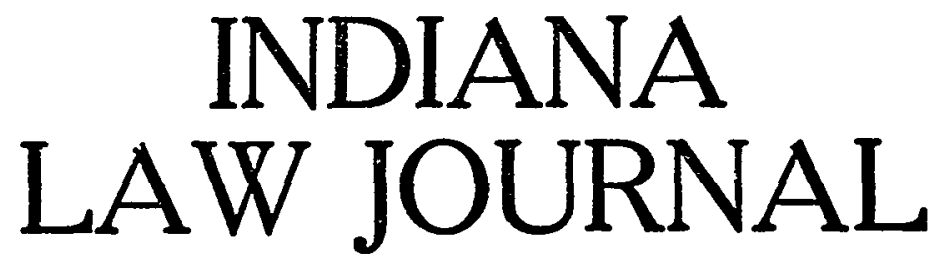

Vol. VI

JANUARY, 1931

No. 4

THE CODE CAUSE OF ACTION: JOINDER AND COUNTERCLAIMS*

BERNARD C. GAVIT**

I

There are five situations where the law struggles with the question, What is a cause of action? The problems are:

(1) The proper application of the code provision that "the complaint shall contain a plain and concise statement of the facts constituting a cause of action."

(2) The proper application of the code provision that a party may join two or more causes of action "arising out of the same transaction or transactions connected with the subject of the action."

(3) The proper application of the code provisions that the defendant in his answer may file a counterclaim on "a cause of action arising out of the contract or transactions set forth in the complaint, as the foundation of the plaintiff's claim, or connected with the subject of the action; and in an action on contract any other cause of action on contract."

(4) The proper application of the provisions of the code permitting amendments; that is, when does an amended pleading state a new cause of action?

* Originally published in Columbia Law Review, Vol. 30, p. 802. Republished here with the consent of the editors of that periodical. Articles dealing specifically with the Indiana statutes and cases on Joinder of Actions and Counterclaims and Set-offs are being prepared by Professor Gavit.

** See biographical note, p. 260. 
(5) The proper application of the rule that a prior adjudication bars a subsequent action on the same cause of action.

The first problem in each instance is, What is a cause of action? To find the correct answer we become involved in an inquiry into our theories as to the fundamental nature of substantive rights and judicial proceedings. In the second and third classes we have also the problems as to what were the legislative intentions expressed by "arising out of the same contract or transactions," and "connected with the subject of the action." The answer to the first problem has considerable bearing on the problems involved in the latter. In general the results which the present article reaches are as follows:

(1) "Cause of action" means a specific substantive right as a matter of substantive law;

(2) The only proper interpretation of the joinder and counterclaim statute allows a joinder of an action or an answer on a counterclaim whenever there is cause in fact between the facts alleged in the pleadings in question. The test is, "But for" one fact in the one pleading, would the fatual situation involved in the others have existed?

(3) To reach the proper solution of the amendment and res judicata cases we must re-frame the rules of law, rather than re-define the "cause of action" to mean "the facts."

\section{II}

It is well, at the outset, to make clear what the author means by "substantive right." Where a necessity has arisen for distinction between "substance" and "procedure" there have been developed at least two classifications as to "rights" and "remedies." Professor Pomeroy classifies them as follows: (1) primary right, (2) remedial right, and (3) remedy. The right against trespass and the right to the performance of a contract are primary rights, while the rights to compensation for invasion of the first or a breach of the second are remedial rights. ${ }^{1}$ The remedy "is summed up or embodied in the judgment of the court."2

There are two objections to this classification. In the first place it assumes that the courts deal only with the "remedial rights." Ordinarily this is true, but there are any number of

1 Pomeroy, Code Remedies (5th ed. 1929), Sec. 1, 2.

2 Ibid., Sec. 347. 
instances where the courts deal with the primary rights, either directly or indirectly. Take, for example, the case where by statute the owner of real estate is entitled to quiet his title as against "the whole world." Suppose there is only a possibility that D might assert an adverse claim; in such a case there has been no invasion of his primary rights; there is only a possibility of such an invasion, and the judgment in such a case is a recognition or re-affirmance of his primary rights in connection with the land and as against $\mathrm{D}$, and is not a recognition of any remedial or secondary right, which arose out of an invasion of those rights by D. ${ }^{3}$ Or, again, take for example, the ordinary suit for an injunction against threatened or contemplated invasions of the plaintiff's primary rights. Here the judgment is not a recognition of any remedial rights as that phrase is used by Professor Pomeroy, but is solely a recognition of the plaintiff's so-called primary rights. ${ }^{4}$

The second objection here is that the calling of the judgment "the remedy" is needlessly confusing. The truth is that the legal profession usually regards the machinery by which the judgment is obtained and enforced as the "remedy" rather than the judgment itself. Obviously it serves no good purpose to rename the judgment "ihe remedy."

The other classification in vogue is that which divides rights into (1) primary rights, (2) secondary rights, (3) remedial rights. Perhaps the most concise statement of this classification is by Dean Goodrich. "The learned author agrees with Professor Pomeroy's classification as to "primary rights." But he says, "So when someone interferes with this 'primary right," the law gives the plaintiff a 'secondary right,' a substitute for the first right now destroyed, by which the injured party is

3 For such a case see Robinson v. Kerrigan, 151 Cal. 40, 90 Pac. 129 (1907).

-Is a decree for specific performance of a contract a recognition of a primary right, or a remedial right? In equity is the contract broken? If it is, of course "specific performance" is a misnomer. Professor Langdell was always very careful to use the phrase "specific reparation," rather than "specific performance." See Langdell, A Brief Survey of Equity Jurisdiction (1888), 1 Harv. L. Rev. 355, 358. But it might well be questioned at this time whether the courts have not given such content to "specific performance" that it is now that, rather than "specific reparation." Quaere, also, as to specific restitution and specific reparation in the field of equitable torts.

5 Goodrich, Handbook on the Conflict of Laws (1927), 158. 
given a claim against him who hurt him. Then, if this secondary right for reparation is not satisfied, the law gives a 'remedial right' created to secure its actual enforcement. . . . There is a marked distinction between a secondary right $(i . e$., the claim for reparation for wrong done) and a remedial right (i. e., the means given for enforcing the claim)."

There are three objections to this classification. The first is the same as that first urged as against Professor Pomeroy's; that is, it is in truth not necessary that there be an invasion of one's primary rights before he can call upon the courts for judicial recognition of his rights. The second is that Dean Goodrich postpones the creation of the so-called "remedial right" until after "this secondary right for reparation is not satisfied." The truth is that one may apply to a court for judicial recognition of the so-called secondary right without any prior negotiations as to its satisfaction. ${ }^{6}$ The third objection is as to the use of the phrase "remedial right" as meaning "the means given for enforcing the claim." The truth again is that it is not a "right." As against the government it is only a privilege. ${ }^{7}$ And as against the defendant it is a duty or liability rather than a right; that is, the defendant has a right that the plaintiff seek judicial recognition of his claimed right rather than attempt to enforce it himself under the old law of selfhelp. 8

It is submitted that both classifications are inaccurate and misleading. It is believed that it is sufficiently discriminating to call what the plaintiff is seeking judicial recognition for in any judicial proceeding his "substantive right." And "right" here must be understood in its broadest sense, that is, as including, for example, a privilege or a power. For it may be that what the plaintiff is asserting is not a right, strictly speaking, but only a privilege. For example, if plaintiff brings an action of mandamus to compel a court to accept jurisdiction of his action, he is seeking judicial recognition of his privilege to use the courts of the state as against some judge's refusal to recognize the privilege.

6 See infra, notes 21 and 22.

7 If there is one proposition of law upon which one might be permitted to make, successfully, a dogmatic statement, it is that there is no right to procedural law. For example, it is too well settled to need citation of authority that the state may change the law of procedure retroactively.

8 See infra, pp. 207, 208. 
At least it is believed that it is safe to say that the courts have so far regarded it as a privilege; that their theory has been that they are recognizing the state's right against the judge, and the judge's duty toward the state, rather than the litigant's right against the state and the judge and their duty toward him.

But if that example is questionable, the proposition is proved by the cases where a plaintiff seeks rescission of a contract or deed, whose execution was induced by the defendant's duress or undue influence. There is no right against duress or undue influence, and clearly what the plaintiff asserts is a privilege of rescission. It is also probably true that when (in the socalled lien theory states) a mortgagee brings a suit to "foreclose" his mortgage, he is really only seeking judicial recognition of a power of sale which the mortgagor granted him, and which the law forbids being exercised by a private sale.

\section{III}

In the law of pleading we are inevitably dealing with some substantive right. There is a sharp distinction between it and the law of procedure. It is asserted here that in every instance the plaintiff comes into court seeking judicial recognition of a substantive right; that procedural law never becomes any part of it; that the judgment or decree is the same right in another form.

The difficulties which the courts and writers have encountered seem to arise out of misconceptions as to our legal history and legal theories. It is necessary, therefore, to consider the historical aspects of the problem.

\section{What is PROcenURAL LAW?}

Procedural law necessarily arose out of the principle which, at first in part, and finally almost completely, did away with the law of self-help. ${ }^{\circ}$ (Unless, of course, we say that the law of self-help was procedural; is so, at least, it was clearly something quite different from what we know as procedural law today.)

0 We still have remnants left of course. For example, one may still abate a nuisance after notice and without breach of peace. See Lemmon v. Webb (1895), A. C. 1. 
Suppose in the twelfth century that A stole B's chattel. The tort which A committed, as a matter of substantive law, was similar to the same tort today. The law was then, as it is now, that $B$ had a limited legal right to get his chattel back. The government, however, gave him little, or no, assistance, other than indirectly and for a brief time, to protect him in his endeavors to re-possess himself of his chattel.10 His remedy was a remedy of self-help; but in the last analysis he was judging and enforcing or executing his substantive legal right to the possession of his chattel.

The difficulty with that was that it was uncertain in its results and tended to produce public disturbances. The government finally said to B, "You shall not determine the existence of and enforce this legal right to the possession of your chattel yourself; we will determine the existence of and enforce it for you through the judicial and the executive departments of the government." When this principle against self-help went into effect, it is not proper to say solely that $B$ had the privilege of applying to the courts and the executive for the recognition and enforcement of his rights; he had also the duty of so applying. The state at least had a right that he so apply and it is quite likely that his adversary had a similar right. The right, of course, was conditional; that is, B's duty here was to apply to the court if he would insist on a satisfaction of his right.

That is as true today as it was then. The rules as to the judicial recognition and executive enforcement of legal rights have a two-fold purpose; they are not only to assist one in the final enforcement of the substantive legal rights; they are also for the purpose of prohibiting one from judging and enforcing his own supposed rights.

\section{WHAT THEN IS A REMEDY?}

In this connection we often see it said that there is no right without a remedy; that, therefore, the remedy is part of the right. ${ }^{11}$ The truth is that our theory has been that a right created by the substantive law exists quite independently of any remedy. At this point the proponents of the opposite view have made a distinction between the so-called primary and sec-

10 Ames, Lectures on Legal History (1913), 178.

11 See, for example, Jacobus v. Colgate, 217 N. Y. 235, 111 N. E. 837 (1917). 
ondary or remedial rights. It is supposed that they would not deny that the so-called primary rights exist (in contemplation of law) without regard to the question of a remedy for their enforcement; that their existence is solely a question of the substantive law, uninfluenced by the law of procedure. It is submitted that there has been no distinction on this score between the so-called primary and secondary or remedial rights. As to the latter, our theory is that whenever as between $A$ and $B$ a factual situation arises which is in truth a violation of a right imposed by law, there is created a substantive right to compensation, restitution, performance, or some other legal equivalent. It is something different from either the facts or the rule of law which call it into being; it is a new right.

The manner of B's ultimate enforcement of this right is wholly beside the point; in truth he may have no actual, or legal, means of enforcement, but still this right exists. It is intangible, but in contemplation of law it has an existence, with so-called attributes of substance. B may sell it (usually); the state taxes it; a neighboring state may make it the basis of a proceeding in rem against $\mathrm{B}$; any civilized nation will recognize its existence and lend its governmental machinery to its final enforcement.

That it exists regardless of the remedy, and, in fact, although there in truth be no remedy, may be illustrated by the following cases. Suppose $A$ and $B$ in state $X$ enter into an oral executory contract for the purchase and sale of goods; the Statute of Frauds of State $\mathrm{X}$ provides that no action shall be brought upon such a contract. The parties obviously have no "remedy" in state $X$. But there is a substantive right there; State $X$ would recognize the validity of another contract whose consideration arises out of this one $;^{12}$ and state $Y$ whose Statute of Frauds provided that such a contract was void (and which statute therefore was a matter of substantive law and could apply only to contracts entered into in state $Y$ ) ought to lend its judicial and executive machinery to the recognition of and enforcement of B's right. ${ }^{13}$ Or suppose that there is a contract

12 See 1 Williston, Contracts (1920), § 199 and cases there cited. Cf., Willis, The Statute of Frauds (1928), 3 Ind. L. J. 427, 533.

131 Williston, op. cit, supra note 12, $\$ 600$; Goodrich, op. cit. supra note 5, 175, 176. See, also, Western Union T. Co. v. Brown, 234 U. S. 542. 547, 34 Sup. Ct. 955 (1914): "It is established as the law of this court, that when a person recovers in one jurisdiction for a tort committed in 
between partnerships having a common partner. There is again, clearly, a contract right which is unenforcible because of the procedural disability forbidding one person to be both plaintiff and defendant. There is no remedy; but the promisees may assign their right to $\mathrm{X}$, who has no trouble in maintaining an action upon it. ${ }^{14}$

\section{IV}

\section{Do The Courts CREate OR ENFORCE Rights?}

Another difficulty arises out of the assumption that the courts create and/or enforce rights. The courts never do either.

The courts do not create rights. Again, apparently, it has been assumed that there is a distinction here between the socalled primary and secondary or remedial rights. It is supposed that few would care to deny that our theory as to the so-called primary rights has been that they exist regardless of court action. It is submitted again that as to the so-called secondary or remedial rights our theory has been the same. The courts here also may conceive of a rule of law so that it in truth has nunc pro tunc effect; but a rule of law is, of course, only a mental concept, and it was only one of the elements of this substantive right which $B$ has. The other element is human action. Our theory has always been that the rule of law, when applied to a given factual situation, ipso facto created this new substantive right. The latter has an existence in contemplation of law before the court ever is called upon to act and even if, in the more usual case, the court never is so called upon. It is true that when the courts change the common law, they are in effect legislating, ex post facto; our theory has been, however, and still is, that the rule now declared operated as if it in truth existed at the time in question.

If it be urged that to give a rule of law nunc pro tunc effect is somewhat of a mental feat, it can well be answered that to give a rule of law ex post facto effect is likewise a mental feat

another, he does so on the ground of an obligation incurred at the place of the tort that accompanies the person of the defendant elsewhere, and that is not only the ground but the measure of the maximum recovery." (Per Holmes, J.)

141 Williston, op. cit. §308; Law of Contracts Restatement (Am. L. Inst.), § 17; Pitcher v. Barrows, 17 Pick. 361 (Mass. 1835). 
of about the same caliber. The author does not feel called upon to choose between them; the assertion here merely is that our theories have long been that the violation of a legal right ipso facto brings into existence an intangible right, which is sui generis, and which in contemplation of law has an existence as a legal right which is entirely separate and distinct from either the facts or the preceding rule of law which brought it into existence.

Again it may sell; and he does not sell a law suit; he sells, for example, his substantive right to compensation. ${ }^{15}$ It passes to his administrator on his death; the state may tax it as property, and it may tax the privilege of inheriting title to it. It has, in contemplation of law, a substantial existence regardless of any court action.

The courts do not enforce rights. The executive department of the government enforces rights; the court merely determines their existence in law and fact, and its judgment operates to cut off either the actuality or the possibility of A's dispute as to the law or the facts and/or operates to put B's substantive right to compensation (for example) into a form which the executive department can and will enforce. The judicial function is the recognition of rights, not their enforcement.

Suppose again that A steals B's chattel. B ipso facto acquires (among others) a substantive right to the re-possession of the chattel.

Suppose B does apply to the court; what happens? A may dispute the facts and the law, and the court determines from the law and the facts which party is entitled to the possession of the chattel. If it finds for $B$, what does it do? It enters judgment that $B$ "have and recover the possession of the chattel of and from A." B's substantive right is still essentially what it was; a right to the possession of the chattel, but it is now in the form of a judgment. But he may not yet go and himself re-take possession. He applies to the clerk for a writ of execution; such a writ is issued, directed to the sheriff commanding him to take the possession of the chattel from $A$ and deliver it

15 See, for example, Manley v. Park, 68 Kan. 400, 75 Pac. 557 (1904). (An assignment of a "chose in action" for the purpose only of assignee's bringing an action on it nevertheless transfers legal title and the assignee is the "real party in interest." As we have seen, the duty to apply to the courts and executive for relief is an incident to this substantive right, and is not a part of the right.) 
to $B$. The sheriff is exclusively an executive officer. ${ }^{16}$ The enforcement of rights is exclusively an executive function. ${ }^{17}$

This is true even in those cases where we say that a court acts in rem. (The case we have put is in fact such a case.) Even, however, when a court acts in rem, it is dealing with mental concepts as to A's and B's respective rights in relation to specific property; it is not dealing with the property itself. ${ }^{18}$ $A$ judgment by a court that $A$, in possession of real property, is the owner in fee simple as against $B$, is essentially a judgment that $B$ has no rights in connection with the real property. A needs no enforcement of such a judgment, just as no negative judgment needs enforcement. In all so-called proceedingis in rem the court is in fact dealing with A's claims against B's claims (or sometimes merely B's possible claim ${ }^{19}$ ). Adverse parties are, therefore, as necessary to a proceeding in rem as they are to a proceeding in personam. ${ }^{20}$

\section{What THEN IS THE "REMEDY?"}

The essentials to the exercise of the judicial powers are a controversy between adverse interested parties, or a request to change an unenforcible substantive right into the form of a judgment right which is enforcible. We usually think of the judicial function as being the settlement of controversies between parties, but in truth courts act although there is no present controversy. Suppose A owes B $\$ 100$. A admits that he owes the money and is willing to pay tomorrow, when he will obtain from $X$ the proceeds of a loan he has arranged for; but, having no money, he cannot pay today. $B$ is, of course, at lib-

16 Knisley v. Ham, 39 Okla. 623, 136 Pac. 427 (1913).

17 See Conflict of Laws Restatement (A.m. L. Inst.), No. 2, § 61, and in particular, Illustration (c), to the effect that a decree punishing $D$ for contempt is enforced by the executive rather than the court.

18 "The law is never concerned with a physical object as such. The sole subject-matter of law is rights, and rights are in all cases relations between individuals. The relation may be purely between individuals, or it may be between individuals with respect to physical objects, such as chattels or land." Bigelow, Introduction to the Law of Real Property (1919) 36.

19 See Robinson $v$. Kerrigan, supra, note 3.

20 "All proceedings, like all rights, are really against persons." Holmes, C. J., in Tyler $v$. Judges of the Court of Registration, 175 Mass. 71, 55 N. E. 812 (1900). See, also, Bastin v. Myers, 82 Ind. App. 325, 144 N. E. 425 (1924) ; Woodruff v. Taylor, 20 Vt. 65 (1847); Baker v. Baker, $E$ \& Co., 242 U. S. 394, 37 Sup. Ct. 152 (1917). 
erty under the law to start an action today.21 Likewise, if A negligently runs over $B$ with his automobile, $B$ may start and maintain an action, although $\mathrm{A}$ admits his liability. ${ }^{22}$

The result is that $A$ 's duty to perform the legal obligation created by the law in each of those situations is the most absolute of any of the duties imposed by law. B may start the machinery for the judicial recognition and executive enforcement of his right, even though there be no dispute as to its existence in law or fact.222 There is always the possibility of a future controversy or denial of liability. There is also the duty to enforce the legal obligation through the courts and the executive department, if no actual satisfaction has been made, despite A's admission of the liability.

What the court does then (in giving a "remedy") in every case is to change this substantive right from one which is unenforcible, to one which is enforcible, and in the process it deals with the parties' actual or possible dispute as to the existence of the right, and its extent, in law and in fact. Even where there is no appearance or contest by the defendant the court must inquire into the law and facts, ${ }^{23}$ because its function is to give judicial sanction to the enforcement of the plaintiff's right and not to his mere claim of right.

The rule of law which imposes the duty on the judgment defendant to pay or perform the judgment is a rule of substantive law and not procedural law.

The substantive law, then, has to do with the rights, privileges, and duties of persons, and creates or recognizes and measures certain rights arising out of violations of rights. The procedural law has to do with the judicial recognition of those latter rights. It has nothing to do with their creation. These

21 Notice and demand are not conditions precedent to the bringing of an action unless made so by the contract or a statute. See, e. g., Wood $v$. Young, 141 N. Y. 211, 36 N. E. 193 (1894). A's action at the most is only an insufficient tender; but even a complete tender would not defeat the action. See 26 R. C. L. 648 et seq.

22 Notice and demand again are not conditions precedent in the absence of a statute. See 45 C. J. 1048 et seq. Again there would be only an insufficient tender.

24“ B's motive is therefore inmaterial. Johnson v. King-Richardson Co., 36 F. (2d) 675 (C. C. A. Ist, 1930).

23 This is true, unless the law is that a default admits the facts and/or confesses the liability. Inaction there gives rise to a presumption as to the existence of the facts alleged, or the rights asserted. 
substantive rights exist without any procedural law ever being or becoming any part of them. Even in the cases where there is involved a right to unliquidated damages, so-called, it is, after all, the substantive law which measures the right, rather than the procedural law. The amount is in fact fixed by the law of damages, which is substantive law, and again the court merely recognizes the existence of the right so measured.

It is true that courts and writers give procedural law as a supposed reason for a change in the substantive law; but it is an excuse and not a reason. For example, it is said that the code provision to the effect that every action should be prosecuted by the "real party in interest" permitted a third party beneficiary to a contract to sue. ${ }^{24}$ But, of course, the law always was that only the owner of the substantive right could maintain an action based upon it. If a third party beneficiary may maintain an action, it is because as against the promisor he has a substantive right to performance or compensation. Procedural law has nothing to do with the proper determination of that question. ${ }^{25}$ Courts may use the code of procedure as an excuse for extending the substantive law, but it is only an excuse and clearly cannot be a valid reason.

\section{$\mathrm{V}$}

\section{Were Procedure and Substantive LAW EVer The SAME?}

There is another misapprehension on the subject. Judges and writers who might admit the foregoing would, nevertheless, assert that originally the procedural law and the forms of action had a great and direct influence on the substantive law. ${ }^{26}$ If

24 See, for example, 13 C. J. 705-707; also, Masury v. Southworth, 9 Ohio St. 340 (1859).

25 See 1 Williston, op. cit. § 366.

26 For example, Judge Smith says, "In the former days when substantive law was dominated by procedure," and he quotes with approval, "The substantive obligations imposed by law and still influenced by the old forms." [Robert Campbell, Principles of English Law, (1907) 425], Smith, Tort and Absolute Liability-Suggested Changes in Classification, (1917), 30 Harv. L. Rev. 245, 246; cf. Bohlen, The Rule in Rylands v. Fletcher, (1911) $59 \mathrm{U}$. of $\mathrm{Pa}$. L. Rev. 312. "But, however procedurally important these differences, they are purely external to the defendant's conduct, and do not affect the fundamental nature of it, nor can they in any way determine its innocence or guilt." 
they mean (which apparently they do) that the law of pleading and practice had such an influence, that is erroneous. The law of pleading and practice had no more direct influence on the substantive law seven or eight hundred years ago than it has today and for the same reason.

Originally substantive rights were co-extensive with the jurisdiction of the courts, but not with the rules of pleading and practice. It probably is true that as distinguished from the law which creates a substantive right, the law of jurisdiction of the courts is adjective law. We do not, however, ordinarily speak of it as procedural law; and it is in fact quite distinct from that body of rules which has to do with court procedure. In fact it forms a third classification, the law of jurisdiction.

Originally it was important from a substantive point of view, because legal liability was specific and jurisdiction of the courts was specific; the two necessarily had to coincide. The administration of justice was a personal function of the King. It came to be exercised by delegation of power in each instance to a judge (and later a court), who acted as an agent or representative of the king. The court's power (or jurisdiction) extended only to the bounds of the delegation. This delegation was made by a writ issued by the chancellor; it was both the foundation of the court's jurisdiction and a summons to the defendant. ${ }^{27}$

The issuance of writs at first was a matter of grace and therefore the complaining party was called upon to give the grounds of his complaint to the chancellor. The writ was issued to cover that situation. Legal thinking in those days had at least some of the attributes of legal thinking today; there was a tendency to classify rights and liabilities and to give different names to situations which were in fact different.28 The result was that when A broke B's close, A committed the tort of trespass quare clausum fregit. It does not make any difference whether the Chancellor called it that first, or whether the courts named it that. The result was that when B applied to the chancellor's office for a writ, complaining that $A$ had entered upon his real estate without right, the chancellor issued a writ authorizing

27 Keigwin, Cases in Common Law Actions (1928), 12.

28 Quite recently, when we created the tort of "Unfair Competition," we gave it not the name of "Tort," but a specific name. And it is a specific liability. See, for example, International News Service v. Associated Press, 248 U. S. 215, 39 Sup. Ct. 68 (1918), commented on in (1918), 13 Ill. L. R. 708. 
the court to inquire into that situation, but he left out the detailed facts and authorized the court to inquire into a trespass quare clausum fregit.

Probably both as a result of the chancellor's abbreviations and the lawyers' and judges' tendency to classify things, legal liability became very distinctly specific. If $B$ did certain acts he committed the tort of trespass quare clausum fregit; if he did other things it was the tort of trespass de bonis asportatis; if he did other things it was the tort of conversion; if he did other things it was a breach of covenant. The law of pleading had nothing to do with that; the law of pleading was essentially then what it is now, that is, that a party must state the facts constituting a substantive right. 29 What was a substantive right was then a question of substantive law as it is now.

It is true again that the courts used the rules of pleading as an excuse for extending the substantive law, and that by the use of fictions and presumptions new rights were created, and the labels on the rights as previously classified were changed about. ${ }^{30}$ But essentially, again, the courts were changing the substantive law, and offering as good an excuse as occurred to them. We have dropped some of the naivete incident to that system, but we work in much the same way today.

It is also true that a rule of procedure would defeat recovery on a different right than that described in the writ and pleading; that is, the rule against variance between the pleading and proof (which is, of course, an enforcement of the rule that the burden is upon the plaintiff to state the facts in his complaint upon which he relies as giving rise to his substantive right) might defeat the action. But again that merely prohibited him from recovering upon one right when he had described another in his complaint; it had no bearing on the question as to what right the substantive law in truth gave him under the true factual situation between the parties.

\section{OUR LaW OF Substantive Rights Is SPECIFic}

For the reasons given above (and doubtless for others, too) we had and still have a law of specific and not general rights.

29 It is true that a good many things then, as now, in the law of pleading passed for "facts" which were something else. But the theory, then, as now, was that the pleadings stated the facts.

30 Thus the tort of conversion was enlarged under the fictions in trover. Keigwin, op. cit. supra note 27, at 153. 
For example, a trespass is not a tort because it is a tort; it is a tort because it is a trespass. If $P$ sues and recovers for a trespass to real estate, it is because his right is a right for trespass to real estate, and not a general right for tort liability. So long as the law protects different interests in varying degrees, it would seem that it would be not only practical but necessary to continue the specific classifications of substantive rights. For a long time that was inherent in the judicial system, but it was primarily the result of the law of jurisdiction, and not the law of pleading and practice. For example, if $A$ sued $B$ in trespass quare clausum fregit and filed a complaint setting out a trespass on the case or proved one, he failed. This was not primarily because of any rule of procedure, but because the court had jurisdiction to try only a suit involving a trespass quare clausum fregit. $^{31}$ Jurisdiction was specific, not general, and then, as now, jurisdiction in theory and jurisdiction in fact had to coinside. It is true that the rule of procedure against variance might also prohibit recovery; but this rule was not the reason for the theories as to specific rights, but solely the result of it.

Instead, therefore, of the rules of pleading being the reason for our theories as to specific rights, the latter are in truth the raison d'etre of the law of pleading. Because the substantive law still labels an act a trespass, or negligence, depending on the circumstances, it is necessary that the laws of pleading be specific enough to follow out the distinctions.

The dividing line between these specific rights is sometimes rather shadowy, and often quite artificial. So long, however, as the substantive law draws those lines, the laws of procedure must recognize them and must deal with them. There is, therefore, more merit to the doctrine of the "theory of the pleading" than some authorities give it credit for. If it be admitted that we ought not to have specific rights, it does not follow that the law of pleading or practice is to blame for the situation. It did not create it; and moreover it cannot abolish it. Procedural law can only deal with the substantive law as it is.

VI

\section{The CAUSE OF ACTION}

What then does the code mean when it says that the plaintiff must state the facts constituting his "cause of action"; that he

313 Blackstone, Commentaries, 273. 
may join complaints on certain "causes of action"; that the defendant may file an answer on certain "causes of action?" It means and can only mean that "cause of action" equals this specific substantive right which the substantive law creates.

The state of the authorities here is most unsatisfactory. The views are quite divergent, and it is believed that none of them have consciously and concisely expressed the result reached here; but it is submitted that this solution will explain the cases which can be said to be correctly decided, and that in its final analysis the language of the code will bear no other construction.

The divergent views expressed by the courts and text-writers seem to fall into the four following general classes. The cause of action consists of :

1. The so-called primary right (and its correlative duty) plus the delict or wrong (the invasion of the right, or violation of the duty).

2. The delict or wrong ( $i$. e., the invasion of the right or violation of the duty).

3. The facts (involved in the judicial proceeding in question).

4. The substantive right.

Professor Pomeroy is the author of the first view, and most of the courts have seemed content to accept it as substantially correct. ${ }^{32}$ Substantially this same view was held by Judge Phillips. ${ }^{33}$

The authorities for the second view, that is, that the cause of action is the delict or wrong, are Judge Bliss and Professor Martin. The former says: "The 'cause of action' then is the wrong." 34 The latter says: "The ordinary action at common law was an adversary proceeding in a court of justice, in which one party sought to render another party liable by judgment of court for the infringement of some legal right. This infringement constitutes the right of action or right of recovery as known at common law and is embraced in the modern term cause of action." 35

The principal exponents of the third view are Dean Clark and Professor McCaskill. Both assert that the cause of action is the facts; they differ in that the latter says that the cause of action

32 Pomeroy, op. cit. supra note 1, 528 et seq.

33 Phillips, Code Pleading (1896), § 30.

34 Bliss, Code Pleading (3d ed. 1894), 190.

85 Martin, Civil Procedure (1905), 7. 
is the specific facts which would be considered under the substantive laws as constituting one right, while the former asserts that there is, or ought to be, a code cause of action, which consists of all of the facts which might be involved in any single or multiple judicial proceeding under the code.

Dean Clark says this: "The codifiers seem to have had in mind the cause of action as consisting of facts which should afford ground or occasion for the court to give judicial relief of some kind, but as not limiting the form or amount of such relief. The cause of action must, therefore, be such an aggregate of operative facts as will give rise to at least one right of action, but it is not limited to a single right (if it is ever possible to isolate one such right from others). The extent of the cause is to be determined pragmatically by the court, having in mind the facts and circumstances of the particular case. Such extent may be settled by past precedents, but the controlling factor will be the matter of trial convenience, for this is the general purpose to be subserved by these procedural rules." 36

Professor McCaskill says: "I think we are now prepared to give a fairly accurate definition of the cause of action. It is that group of operative facts which, standing alone, would show a single right in the plaintiff and a single delict to that right giving cause for the state through its courts, to afford relief to the party or parties whose rights are invaded. The singleness of the right and delict is determined by a study of the old remedies in connection with which the concepts as to singleness of rights and delicts developed." 37

There is at least one decision defining the cause of action as the facts. ${ }^{38}$

\section{CRITICISM OF These Views}

The results of the first four probably are not essentially different from the results here reached. Indirectly they appear to regard the "cause of action" as the substantive right involved. That is, they regard the cause of action as its elements (or part of them), rather than the resultant substantive right created by those elements. At this point (in the usual case) no particular

${ }^{36}$ Clark, Handbook of the Law of Code Pleading (1928), 83-85.

37 McCaskill, Actions and Causes of Action, (1925) 34 Yale L. J. 614, 638.

38 Hutchinson v. Ainsworth, 73 Cal. 452, 15 Pac. 82 (1887). 
harm is done by these definitions, because when one pleads the facts constituting or giving rise to a cause of action, he in truth pleads the facts showing the so-called primary right plus a violation of it. In those cases, however, where the plaintiff relies upon a so-called primary, rather than a so-called secondary or remedial, right, the definitions are inaccurate; for there has been no delict or wrong as yet. So the first four definitions are at least insufficient here, and when one comes to the joinder and counterclaim provisions of the code, their absolute inaccuracy is displayed.

The principal quarrel at this point is with the last two. Both define the "cause of action" as being the "facts" involved. It is submitted that the code permits of no such construction.

If the legislature and the authors of the code had thought that the "cause of action" was "the operative facts," quite clearly they would not have said that the plaintiff was to state the facts constituting his cause of action; they would have said that he was to state his cause of action. Clearly they must have considered that there was some distinction between "the facts" and "the cause of action," but that, however, "the facts" entered into and helped to make up or "constitute" the "cause of action." They were dealing with a rule of pleading; they knew that the rules of pleading did not require the plaintiff to plead the law. That most reasonable inference must be read into the code. Properly paraphrased the code would read: "The plaintiff in his complaint shall state the (operative) facts which (together with a rule of law) constitute (or malie up) his (specific substantive right.)" Facts alone, it is submitted, never did and never can create or constitute a "cause of action." The facts (which the plaintiff must plead) plus a rule of law (which he must not plead) create a substantive right upon which the plaintiff relies and for which he seeks judicial recognition. The facts plus the law constitute or bring into being this substantive right, or "cause of action."

The joinder statute bears this out. It says that "the plaintiff may unite in the same complaint, two or more causes of action, whether they were such as were formerly denominated legal or equitable." There is no such thing as a legal or equitable operative fact; there is a legal or equitable right. Property paraphrased, the statute reads: "The plaintiff may unite in the same statement of his operative facts separate paragraphs on two or more legal or equitable substantive rights." 
The counterclaim statute then, also, is: "The answer of the defendant must contain a statement of any new matter constituting a counterclaim, which must be one of the following substantive rights." The word counterclaim equals "cause of action;" the statement of the operative facts is put in an "answer" and not in a complaint, cross-complaint, or counterclaim. But it is plain again that the code is dealing with a rule of pleading. The defendant is to set up new matter (facts) which, together with a rule of law, "constitute" a substantive right. Is it not plain in each instance that "cause of action" means "specific substantive right as a matter of substantive law?"

\section{VII}

\section{The CaUse of ACTion and the Amendment Statutes}

The amendment provisions in the code are to the effect that "any pleading may be amended," or a party may be allowed "to amend his pleading." Necessarily the amendment is some change, not only in the physical pleading, but in the statement of facts contained in the pleading. A party has made a mistake in his statement of facts; or it is insufficient in law, and he is permitted to correct the mistake or insufficiency by filing an amended pleading.

How far a party should be permitted to go in making changes in his pleading of the facts upon which he relies depends quite obviously on a proper interpretation of the amendment statutes. Ordinarily there is no object in making an amendment except as to some material allegation and it ought to be no valid objection that the change is material, or even radical. It can only temporarily inconvenience the other party in his trial or presentment of the case, and that can be taken care of by the allowance of a continuance or other appropriate relief.

The real difficulty arises in the application of the supposed rule that, as far as the statute of limitations is concerned, if the amended pleading states a new cause of action, the action is started when the amended pleading is filed. Are we dealing with the amendment statutes, or the statute of limitations? The latter usually provides that "no action shall be brought" etc., or "the following actions shall be brought" etc. "Action" here means "judicial proceeding," and has obviously no connection with, or similarity to, a "cause of action." 
What is the question involved? It is, when was this judicial proceeding brought, when the original or when the amended complaint was filed? The rule has been stated to be that it is the former, or the latter, depending upon whether or not there is substituted a new "cause of action."39 Or in other words, do the new facts give rise to a different substantive right?

We are in truth dealing with both statutes and if the rule is as thus stated, the inquiry gets back then to what do we mean by "cause of action?" It has been held that it means and can only mean substantive right, as specifically determined by the substantive law. If the rule be put in this form, the result quite logically is rather harsh.40 What is the remedy? Dean Clark suggests again that it is to define "cause of action" to mean "facts."

With due deference to Dean Clark it is submitted that such a definition of "cause of action" to take care of the amendment and res judicata cases, destroys the real distinctions between substance and procedure involved in every law suit. He says in this connection, ${ }^{41}$ "The term (cause of action) should be interpreted as referring to facts upon which one or more rights of action ${ }^{42}$ are based rather than on the rights themselves. Hence a mere change in legal theory only should not be considered the statement of a new cause."

But it is submitted that the way out of the difficulty is the one which the courts have in truth used, where they have escaped and reached a more desirable result..3 In effect they have said the test is not, "Does the amended complaint state a new cause of action?"; but it is, "Was the defendant reasonably apprised of the right, or rights, which the plaintiff did, or might (under the amendment statutes) claim based on the factual situation

89 N. \& G. Taylor Co. v. Anderson, 275 U. S. 431; 48 Sup. Ct. 144 (1928).

40 See, for example, the case cited supra note 39 , and the comment on this case in Clark, op. cit. supra note 36 , at 516. See, also, B. \& O. S.W. R. v. Carroll, 50 Sup. Ct. 182 (1930).

41 Clark, op. cit. supra note 36 , at 514 .

42 Does he not use "rights of action" and "rights themselves" here in exactly the same sense in which we have contended the code uses "causes of action?" He here makes a distinction between "the facts" and "the rights;" we have said that is just the distinction the code makes. As stated heretofore, the code had already dealt with "the facts" and presumptively means something else by "cause of action" when it says "the facts constituting the cause of action."

43 See the leading cases cited by Clark, op. cit. supra note 36, at 513-515. 
attempted to be set out in the complaint?" That is, the rule is that an action is "brought" or "commenced" within the meaning of the statute of limitations when by amendment its factual situation is connected in some more or less substantial manner in fact to that alleged in the original complaint.

The rule really involved here is that an amended pleading (although it be based on an essentially different substantive right) is considered filed as of the time of the filing of the original pleading. This rule is a pure fiction for the benefit of the parties. There is no objection to applying it to take care of this difficulty. As against the statute of limitations the courts have sometimes refused to apply it.

If it is applied, the result is that after all a defendant, when an action is begun against him, is called upon to defend not only the claims of substantive right described in the complaint, but any other which may result from an application of statutes on amendments. He knows that in truth he may be called upon to defend something essentially different from that which is now set out, so long as it has some connection in fact. For the purposes of the statute of limitations the filing of the original complaint is the beginning of the action, which includes the later amendments although they be quite radical in their nature.

The truth is that what has happened is that the courts unwittingly laid down the rule that if an amendment stated a new "cause of action," the amendment did not relate back to the time of the filing of the original complaint so far as the statute of limitations was concerned. "Cause of action" here could only again mean a "specific substantive right," and the result was undesirable. The obvious remedy is not to change the definition of the "cause of action," but it is to change the rule. It is submitted that that is what the courts have done where they have reached a desirable result. The "cause of action" was dragged in in attempting to frame a rule made necessary by a call for an interpretation of the two statutes; a more just result if it is left out, and there certainly can be no objection to leaving it out. 